\title{
Optimization of the technological solutions for recharge and boron control system at the NPP for the project AES-2006
}

\author{
Anastasia Ulasen $^{1}$, Aleksandr Kalyutik ${ }^{1, *}$ and Anatolii. Blagoveshchenskii ${ }^{1}$ \\ ${ }^{1}$ Peter the Great St. Petersburg Polytechnic University, 29 Politekhnicheskaya street, 195251, Saint \\ Petersburg, Russia.
}

\begin{abstract}
The article considers the possible ways to optimize the technological solutions of the recharge and boron control system of nuclear power plants under construction within the AES-2006 project. The possibilities for optimization of technological solutions of the system of recharge and boron regulation of the AES-2006 project, which will not affect the reliability and efficiency of its main functions: purge-recharge of the primary circuit and boron regulation, were studied. As a result of the analysis of technological solutions and analytical calculations carried out during the work, it was found that in the system of recharge and boron regulation of the NPP within the project AES-2006 it is possible to perform optimization basing on reduction the metal content of the heat exchange equipment by reducing the surface area of the heat exchangers of the coolant outlet, reducing the power of pumps, as well as reducing the diameter of a number of main pipelines. Implementation of the proposed optimization of technological solutions will allow a more rational arrangement of the system and reduce capital costs for the construction of nuclear power plants as a whole, while not adversely affect the safety of the system and its functions.
\end{abstract}

\section{Introduction}

Nowadays development of the nuclear branch of power engineering is of vital importance both for Russia as a whole, and for the North-West district in particularly and a lot of papers are devoted to its improvement [1-8]. The project AES-2006 is a project of Russian nuclear power plant of a new generation " $3+$ " with improved performance characteristics. It is an evolution of the NPP projects with VVER-1000, which was created based on the project AES-91 according to the Federal Targeted Program for development of the nuclear power engineering. Achievement of the goals for development of the Russian nuclear power engineering, which are stated in the Federal Targeted Program, should be based on the existing research and technology solutions. It should reliably provide short commissioning times and performance characteristics, which form the basis of competitiveness of the power-generating units [9]. The project AES-2006 becomes a basis

\footnotetext{
*Corresponding author: Kalyutik@yandex.ru
} 
for designing of such foreign power stations as the NPP Kudankulam in India, the Hanhikivi NPP in Finland (the NPP construction and exploitation will be performed by the Finland nuclear consortium Fennovoima [10]), Paks-2 NPP in Hungary, El-Dabaa NPP in Egypt, etc. The aim of the project is to achieve modern characteristics on reliability and safety at the optimized capital investments for the unit construction [11]. Optimization of the systems for the project AES-2006 is aimed at finding safe solutions for reduction of capital expenses for the unit construction.

So, the problem of optimization of technological solutions for the feeding system and boron control of the nuclear power plant of the AES-2006 project are of immediate interest due to wide application of this project for the power plant construction both in Russia and abroad [12].

The objects under investigation are nuclear power plants, which are constructed according to the AES-2006 project.

The subject of investigation is the system of feeding and boron control, which is a part of auxiliary systems of the reactor unit.

The main system functions are the following:

- Maintaining the material balance of the coolant of the first contour during the exploitation modes: start, stop, power operation;

- $\quad$ Managing the reactor reactivity;

- Maintaining the water-chemical mode of the coolant of the first contour during the exploitation modes: start, stop, power operation;

\section{Aim of the work}

The aim of this work is investigation of possibilities for optimization of the technological solutions for recharge and boron control system of the AES-2006 project. Another one aim is searching for a way for reduction of capital investments, which will not have an influence on its major function performance reliability: blowdown-feeding of the first contour and the boron control. The research work was performed using the analysis of technological solutions and analytical calculations.

The optimization of technological solutions might be performed in some directions. The highest interest for the system of boron control lies in the economical optimization, because of the system complexity and its high degree of branching.

The main way for increasing the system profitability is equipment cost-cutting, which might be achieved by decreasing the metal content of the heat-exchange equipment, reduction of the power consumed by the pump stations, and decreasing the diameters of the system pipelines.

Consequently, now there is a task for optimization of capacities and dimensions of the system equipment, which won't lead to deterioration of the system reliability.

During our investigation we have performed the following calculations:

1. Calculation of capacity consumed by the pumps;

2. Heat calculation of the heat-exchange equipment;

3. Hydraulic calculation of the major system pipelines.

Calculations of the capacity consumed by the feeding pumps of the "high" and "low" efficiency, as well as by the hydraulic test pump were performed according to the following formulas [13], [19-21]:

The capacity used for the energy transmission to the pumped fluid $\mathrm{Np}$ is:

$$
N_{p}=\rho \cdot g \cdot Q \cdot H
$$

Where $\rho$ is density of the pumped fluid;

$g$ is gravity acceleration;

$Q$ is consumption; 
$H$ is total pressure head.

The capacity at the pump shaft $N_{s h}$ is:

$N_{p}$ is operating capacity, W;

$$
N_{s h}=\frac{N_{p}}{\eta_{p}}
$$

$\eta_{p}$ is pump efficiency;

The engine capacity $N_{e}$ is:

$N_{s h}$ is capacity of the pump shaft;

$$
N_{e}=\frac{N_{S h}}{\eta_{t r} \cdot \eta_{e}}
$$

$\eta_{t r}$ is transmission efficiency;

$\eta_{e}$ is engine efficiency.

The final installed capacity of the engine $\mathrm{Ni}$ is:

Where $N_{e}$ is capacity consumed by the engine;

$$
N_{i}=\beta \bullet N_{e}
$$

$\beta$ is capacity safety factor.

The capacity safety factor was chosen to be 1.1 .

We also performed heat design calculations of the heat-exchange equipment for brazedplate and shell-and-tube heat exchangers.

The calculations for shell-and-tube heat exchangers were performed in a following way $[14,15,17,24]$ :

For selection of the necessary typical size we have preset the optimum velocity of the heating water in pipes: $w_{\text {req }}=1 \mathrm{~m} / \mathrm{s}$. On the assumption of two-flow arrangement we have determined the necessary pipe section $f_{\text {req }}$ rel:

$$
f_{t s}^{r e l}=\frac{G_{2}}{2 \cdot w_{r e q} \cdot \rho_{2}}
$$

According to the obtained value we have chosen the necessary typical size of the water heater [15].

For the chosen typical size we determined the actual water velocity in and outside the pipes:

$$
\begin{gathered}
w_{p}=\frac{G_{2}}{2 \cdot f_{p} \cdot \rho} \\
w_{o p}=\frac{G_{1}}{2 \cdot f_{o p} \cdot \rho}
\end{gathered}
$$

Heat emission coefficient from the heating water to the pipe wall $\alpha_{1}$ :

$$
\alpha_{1}=1.16 \cdot\left[1210+18 t_{1 a v}-0.038 t_{1 a v}^{2}\right] \cdot \frac{w_{o p}^{0.8}}{d_{e k v}^{0.2}}
$$

Heat transfer coefficient from the pipe wall to the water being heated $\alpha_{2}$ :

$$
\alpha_{2}=1.16 \cdot\left[1210+18 t_{2 a v}-0.038 t_{2 a v}^{2}\right] \cdot \frac{w_{p}^{0.8}}{d_{i n}^{0.2}}
$$

Heat transfer coefficient of the water-heating unit $\mathrm{k}$ :

$$
k=\frac{\psi}{\frac{1}{\alpha_{1}}+\frac{1}{\alpha_{2}}+\frac{\delta_{s t}}{\lambda_{s t}}}
$$

where $\psi$ is heat-exchange efficiency, which is set to be $\psi=1.2$ for the bare-tube heatexchanger with a set of midfeathers.

The area of heating surface for the water heater $\mathrm{Fw}$ is:

$$
F_{w}=\frac{Q}{k \Delta t}
$$

where $\mathrm{Q}$ is calculated efficiency of the water heater, $\Delta \mathrm{t}$ is $\log$ mean temperature pressure head.

$$
\Delta t=\frac{\Delta t_{\max }-\Delta t_{\min }}{\ln \frac{\Delta t_{\max }}{\Delta t_{\min }}}
$$


The amount of sections of the water heater in one flow $\mathrm{N}$ is:

The actual heat-exchange area $\mathrm{F}$ is:

$$
N=\frac{F_{w}}{2 f_{\text {sec }}}
$$

$$
F=2 \cdot N \cdot f_{\text {sec }}
$$

The calculations for brazed-plate heat exchangers were performed in a following way $[14,15,17,24]$ :

The relation between the number of passes for heating water $X_{1}$ and for the water being heated $\mathrm{X}_{2}$ is:

$$
\frac{X_{1}}{X_{2}}=\left(\frac{G_{h}}{G_{b h}}\right)^{0.636} \cdot\left(\frac{\Delta P_{h}}{\Delta P_{b h}}\right)^{0.364} \cdot \frac{1000-t_{a v}^{b h}}{1000-t_{a v}^{h}}
$$

At the ratio of passes not exceeding 2 one use the symmetrical arrangement.

Optimum velocity of water in channels is assumed to be $\mathrm{w}_{\text {opt }}=0.4 \mathrm{~m} / \mathrm{s}$ [15]. In our calculations we will use plate of the $0.6 p$ type.

The required number of channels of the water being heated $\mathrm{m}_{\mathrm{bh}}$ is:

$$
m_{b h}=\frac{G_{b h}}{w_{o p t} \cdot f_{k} \cdot \rho_{b h}},
$$

where $f_{\text {ch }}$ is flow section of one interlamellar channel.

As the arrangement of the heater is symmetrical, $m_{h}=m_{b h}$.

Total flow section of the channels in the package along the heating water and the water being heated:

$$
f_{h}=f_{b h}=m_{b h} \cdot f_{k}
$$

Actual velocities of the heating water and the water being heated:

$$
\begin{aligned}
& w_{h}=\frac{G_{1}}{f_{h} \cdot \rho_{1}} \\
& w_{b h}=\frac{G_{2}}{f_{b h} \cdot \rho_{2}}
\end{aligned}
$$

Heat transfer coefficient from the heating water to the plate wall $\alpha_{1}$ :

$$
\alpha_{h}=1.16 \cdot A \cdot\left[23000+283 t_{h_{-} a v}-0.63 t_{h_{-} a v}^{2}\right] \cdot w_{h}^{0.73},
$$

where $\mathrm{A}$ is the coefficient depending on the plate type.

Heat absorption coefficient from the plate wall to the water being heated $\alpha_{2}$ :

$$
\alpha_{b h}=1.16 \cdot A \cdot\left[23000+283 t_{b h_{-} a v}-0.63 t_{b h_{-} a v}^{2}\right] \cdot w_{b h}^{0.73}
$$

Heat transfer coefficient $\mathrm{k}$ :

$$
k=\frac{1}{\frac{1}{\alpha_{h}}+\frac{1}{\alpha_{b h}}+\frac{\delta_{s t}}{\lambda_{s t}}}
$$

The required surface area for heating Freq is:

$$
F_{\text {req }}=\frac{Q}{k \Delta t}
$$

The amount of passes in a heat exchanger $\mathrm{X}$ is:

$$
X=\frac{F_{r e q}+f_{p l}}{2 m f_{p l}}
$$

The actual surface area of heating of the whole water heater $\mathrm{F}$ is:

$$
F=(2 m X-1) \cdot f_{p l}
$$

The calculation of the optimum diameters of the main pipes was carried out using the formula for pipe efficiency calculation $[16,18,23]$ :

where $\mathrm{Q}$ is consumption of the transmitted fluid;

$$
Q=\frac{\pi \cdot d^{2}}{4 \cdot w}
$$

$\mathrm{d}$ is pipes' diameter;

$\mathrm{w}$ is velocity of the flow.

Hence we get the expression for the optimum diameter: 


$$
d=\sqrt{\frac{Q \cdot 4 \cdot w}{\pi}}
$$

The obtained calculation results are presented in Tables 1 and 2.

\section{Results}

We carried out calculation of the consumed power of the pumps, heat calculation of the heat-exchange equipment, hydraulic calculation of the main pipelines of recharge and boron control systembasing on the techniques presented in the technical literature. We have determined the optimum nominal diameters of the pipelines, surface areas of heat exchange for the heat exchangers, the installed capacity of the pumps engines. The calculation results have shown that optimization of the system might be performed taking into account all major safety principles by reduction of the surface area of heating of the heat exchangers and installed capacity of the pumps, and decreasing of the diameters of a number of main pipelines. We have found a way for optimization of the technological scheme for recharge and boron control systemat the NPP for the project AES-2006.

Table 1. The results for the equipment optimization

\begin{tabular}{|l|c|c|c|c|c|c|}
\hline $\begin{array}{l}\text { Equipment } \\
\text { type }\end{array}$ & $\begin{array}{c}\text { Equipment } \\
\text { name }\end{array}$ & $\begin{array}{c}\text { Characteristics } \\
\text { value }\end{array}$ & $\begin{array}{c}\text { Measuring } \\
\text { units }\end{array}$ & $\begin{array}{c}\text { Value } \\
\text { from } \\
\text { calculation }\end{array}$ & $\begin{array}{c}\text { Value } \\
\text { from } \\
\text { the } \\
\text { project }\end{array}$ & $\begin{array}{c}\text { Reduction, } \\
\%\end{array}$ \\
\hline exchanger & $\begin{array}{c}\text { Heat } \\
\text { exchanger of } \\
\text { the emergency } \\
\text { coolant } \\
\text { removal }\end{array}$ & $\begin{array}{c}\text { Surface area of } \\
\text { the heat- } \\
\text { exchange }\end{array}$ & $\mathrm{m}^{2}$ & 10.173 & 14 & 27.3 \\
\hline $\begin{array}{l}\text { Heat } \\
\text { exchanger }\end{array}$ & $\begin{array}{c}\text { Heat } \\
\text { the emanger of } \\
\text { coolant } \\
\text { removal }\end{array}$ & $\begin{array}{c}\text { Surface area of } \\
\text { the heat- } \\
\text { exchange }\end{array}$ & $\mathrm{m} \mathrm{m}^{2}$ & 18.289 & 20.4 & 10.3 \\
\hline Pump & $\begin{array}{c}\text { Hydraulic test } \\
\text { pump }\end{array}$ & $\begin{array}{c}\text { Installed } \\
\text { capacity }\end{array}$ & $\mathrm{kW}$ & 33.2 & 39.8 & 16.6 \\
\hline Pump & $\begin{array}{c}\text { Feeding pump } \\
\text { of "low" } \\
\text { efficiency }\end{array}$ & $\begin{array}{c}\text { Installed } \\
\text { capacity }\end{array}$ & $\mathrm{kW}$ & 55.7 & 60.2 & 7.5 \\
\hline
\end{tabular}

Table 2. The results for the pipeline optimization

\begin{tabular}{|c|c|c|c|c|c|}
\hline Area name & $\begin{array}{c}\text { Characteri } \\
\text { stics value }\end{array}$ & $\begin{array}{c}\text { Measuring } \\
\text { units }\end{array}$ & $\begin{array}{c}\text { Value from } \\
\text { calculation }\end{array}$ & $\begin{array}{c}\text { Value from } \\
\text { the project }\end{array}$ & $\begin{array}{c}\text { Reduction, } \\
\%\end{array}$ \\
\hline $\begin{array}{c}\text { Suction of the } \\
\text { feeding pump of } \\
\text { "low" efficiency }\end{array}$ & $\begin{array}{c}\text { Nominal } \\
\text { diameter }\end{array}$ & $\mathrm{mm}$ & 125 & 150 & 16.7 \\
\hline
\end{tabular}




\begin{tabular}{|c|c|c|c|c|c|}
\hline $\begin{array}{c}\text { Charging of the } \\
\text { feeding pump of } \\
\text { "high" efficiency }\end{array}$ & $\begin{array}{c}\text { Nominal } \\
\text { diameter }\end{array}$ & $\mathrm{mm}$ & 90 & 100 & 10.0 \\
\hline $\begin{array}{c}\text { Aftercooler of the } \\
\text { colant at the suction } \\
\text { of the feeding pumps }\end{array}$ & $\begin{array}{c}\text { Nominal } \\
\text { diameter }\end{array}$ & $\mathrm{mm}$ & 125 & 150 & 16.7 \\
\hline $\begin{array}{c}\text { Regenerative heat } \\
\text { exchanger of the } \\
\text { coolant removal }\end{array}$ & $\begin{array}{l}\text { Nominal } \\
\text { diameter }\end{array}$ & $\mathrm{mm}$ & 100 & 150 & 33.3 \\
\hline $\begin{array}{c}\text { Heat exchanger of } \\
\text { the coolant removal }\end{array}$ & $\begin{array}{l}\text { Nominal } \\
\text { diameter }\end{array}$ & $\mathrm{mm}$ & 150 & 200 & 25.0 \\
\hline Deaerator & $\begin{array}{l}\text { Nominal } \\
\text { diameter }\end{array}$ & $\mathrm{mm}$ & 100 & 150 & 33.3 \\
\hline
\end{tabular}

\section{Conclusions}

It is possible to perform optimization at recharge and boron control systemof the NPP of the project AES-2006 basing on: reduction of metal content of the heat-exchange equipment by decreasing of the heating surface area of the heat exchangers for the coolant removal, decreasing of capacity of the hydraulic test pump and feeding pump of "low" efficiency, and reduction of diameters of the main pipelines. Optimization of the technical solutions based on the provided parameters will allow one to arrange the system in a more rational way and reduce the capital expenses for the NPP construction, at this it won't have a negative impact on the safety of the investigated system as a whole and its functions.

\section{References}

1. M.Y. Egorov, Atomic Energy 124(6), 403-407 (2018)

2. M.Y. Egorov, Atomic Energy 124(2), 139-142 (2018)

3. N. D. Agafonova et al., Atomic Energy 123, 154-158 (2018)

4. E.P. Obraztsov, A.N. Belikov, N.N. Menshikov, E.N. Popkov, E.N. ICAPP 2016 2, 1131-1140 (2016)

5. V.V Legkostupova, A.V. Sudakov, MATEC Web of Conferences 23, 01058 (2015)

6. V.V. Davydov, V.I. Dudkin, E.N. Velichko, A.Yu. Karseev, Journal of Optical Technology (A Translation of Opticheskii Zhurnal) 82(3), 132-135 (2015)

7. Y.E. Karyakin, A.A. Pletnev, E.D. Fedorovich, Journal of Engineering Physics and Thermophysics 90(1), 80-87 (2015)

8. V. Merkulov, IOP Conference Series: Earth and Environmental Science 180(1), 012020 (2018)

9. Project AES 2006. Leningradskaya AES-2. SPb., Atomenergoproekt, 36 (2007)

10. Hankhikivi-1

NPP.

https://en.wikipedia.org/wiki/Hanhikivi_Nuclear_Power_Plant

Wikipedia: 
11. Projects with reactor units of the VVER type [Proekty s reaktornymi ustanovkami tipa VVER] - Concern Rosenergoatom http://archive.atomproekt.com/activitycategories/generation/projects_with_reactors

12. A.S. Ulasen', A.A. Kalyutik, Nedelya nauki SPbPU: materialy nauchnoj konferentsii s mezhdunarodnym uchastiem. Institut energetiki i transportnykh sistem 1, 58-60 (2016)

13. V.Ya Karelin, A.V. Minaev, Nasosy i nasosnye stantsii, 320 (1986)

14. Russian State Standard GOST 15518-87. Plate heat exchangers. Types, characteristics and basic dimensions (1999)

15. Construction Rules SP 41-101-95. Design of the heat supply units (1997)

16. E.X. Odel'skij, Hydraulic calculation of the pipelines for various designations, 103 (1967)

17. O.P. Bannykh, Osnovnye konstruktsii i teplovoj raschet teploobmennikov, 42 (2012)

18. T.N. Il'ina, Osnovy gidravlicheskogo rascheta inzhenernykh setej (2007)

19. V. F. Chebaevskij, K. P. Vishnevskij, N. N. Nakladov, Proektirovanie nasosnykh stantsij $i$ ispytanie nasosnykh ustanovok, 376 (2000)

20. P.V. Lobachev, Pumps and pump stations (1990)

21. A.K. Mikhajlov, V.V. Malyushenko, Constructions and calculation of the centrifuge pumps of high pressure, 304 (1971)

22. OAO «SPbAEP», Basic conceptual solutions on the example of the Leningrad NPP AES-2 (2011)

23. I.E. Idel'chik, Reference book on hydraulic resistances, 466 (2012)

24. A.B. Mozzhukhin, E.A. Sergeeva, Heat-exchanger calculation: guidelines, 32 (2007) 